$\xi=-1$

\title{
Cold LOGIK and RDHX Solution for Data Center Energy Optimization
}

\author{
T. Suresh ${ }^{1 *}$, Dr. A. Murugan ${ }^{2}$ \\ ${ }^{I}$ Research Scholar, PG \& Research Dept of Computer Science, Dr. Ambedkar Government Arts College, Chennai, India \\ ${ }^{2}$ Associate Professor \&Head, PG \& Research Dept of Computer Science, Dr. Ambedkar Government Arts College, Chennai, India \\ *Corresponding author E-mail:thangavelusuresh@gmail.com
}

\begin{abstract}
In all types of data center, keeping the right temperature with less cost and energy is one of important objective as energy saving is crucial in increased data driven industry. Energy saving is global focus for all industry. In Information technology, more than $60 \%$ of energy is utilized in data centers as it needs to be up and running. As per Avocent data center issue study, across globe more than 54\% of data centers are in redesigning process to improve their efficiency and reduce operational cost and energy consumption. Data center managers and operators major challenge was how to maintain the temperature of servers with less power and energy. When the densities of data center energy nearing 5 kilowatts $(\mathrm{kW})$ per cabinet, organizations are trying to find a way to manage the heat through latest technologies. Power usage per square can be reduced by incorporating liquid-cooling devices instead of increasing airflow volume. This is especially important in a data center with a typical under-floor cooling system. This research paper uses Rear-Door Heat eXchangers (RDHx) and cool logic solutions to reduce energy consumption. It gives result of implementation of Cold Logik and RDHx solution to Data center and proves that how it saves energy and power. Data center has optimized space, cooling, power and operational cost by implementing RDHx technology. This will enable to add more servers without increasing the space and reduce cooling and power cost. It also saves Data center space from heat dissipation from servers.
\end{abstract}

Keywords: Data Center Optimization, Cold logic, RDHx, Rear Door Heat exchanger, energy saving, power saving, green computing.

\section{Introduction}

In 2005, Telecommunication Industry Association (TIA) published ANSI/TIA-942 telecommunications infrastructure standard for data center [1]. This standard is amended further four times in $2008,2010,2014$, and recently in 2017. Based on these standards, Uptime Institute classifies data centers into 4 standard types. Table (1) gives details of these 4 tiers and its requirements

Table 1Data Center Tier Description

\begin{tabular}{|l|l|}
\hline Tier & Requirements \\
\hline I & $\begin{array}{l}\text { This is the typical server room maintained by internal IT team of } \\
\text { organization } \\
\text { Single uplink and servers. Non redundant capacity of compo- } \\
\text { nents. No UPS / Generator or optional. } \\
99.671 \% \text { availability. 28.8 our downtime / year }\end{array}$ \\
\hline II & $\begin{array}{l}\text { Tier I + } \\
\text { UPS / Generator Redundant capacity or components } \\
99.741 \% \text { availability. 22 hour downtime / year }\end{array}$ \\
\hline III & $\begin{array}{l}\text { Tier II + } \\
\text { Concurrently maintainable Generator and UPS systems } \\
\text { Duel powered equipment with multiple uplink } \\
99.982 \% \text { availability. 1.6 hours downtime / year }\end{array}$ \\
\hline IV & $\begin{array}{l}\text { Tier III + } \\
100 \% \text { fault tolerant of all components including uplinks, storage, } \\
\text { Heading, Ventilation and Air Conditioning (HVAC) system } \\
99.995 \% \text { availability 0.4 hours downtime / year }\end{array}$ \\
\hline
\end{tabular}

In addition to these 4 tier, the German Data center Star Audit program uses an auditing process to certify five levels of "gratifica- tion" that affect data center criticality which is not acknowledged by any standards.

The Fourth Industrial Revolution (4IR) is described as a range of new technologies cut across social networking, Internet of Things (IoT), Artificial Intelligence (AI), virtual reality (VR), augmented reality (AR), cloud computing, mobility, self-driving vehicles and bio-technology revolution. 4IR generates more data than ever and it is mandatory to manage these data as per business requirement and need. To maintain these data, Data center plays major role and it is important to ensure data center are up and running all time. Ken Brill, father of data center predicted that rate of computational increase is greater than the rate of increase of power (Moore's Law). He also mentioned that the increasing amount of heat resulting from adding more transistors onto a chip requires advanced technologies to control the heat and maintain temperature of data center. The chief executive officer of Google remarked, "What matters most to the computer designers at Google is not speed but power, low power, because data centers can consume as much energy as a city" [2].

As per report from U.S. Department of Energy-led Center of Expertise for Energy Efficiency in Data Centers, U.S. data centers consumed 1.8 percent of the country's total energy consumption. This will go up with the increase of 4IR technology revolution. The report Emerging Trends in Electricity Consumption for Consumer ICT determined that data centers and networks will be the highest growth segments in energy consumption. As per, Emerging Trends in Electricity Consumption for Consumer ICT, in the last 5 years, energy consumption is increasing for maintaining networks and managing data center. Figure (1) shows the comparison of energy consumption between 2012 and 2017 


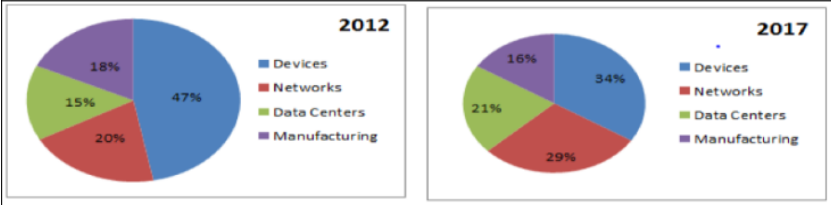

Figure 1Energy Consumption between 2012 and 2017

The American Society of Heating, Refrigerating and AirConditioning Engineers (ASHRAE) have done more research on finding suitable area for keeping IT Equipment (ITE). ASHRAE Technical Committee 9.9 (TC9.9) guidelines are based on server inlet temperature and not as per internal server temperature, room temperature or server exhaust temperature. The lifespan is server will come down when it functions in high temperature and duration of exposure. It suggests that it is not necessarily that ITEs are not kept in cooling condition throughout the year, it can be exposed to heat for more hours each year. To maintain the temperature of data center, the cooling process can be divided into following steps

\subsection{Server Cooling:}

In Data center, ITE generate more heat as it uses electricity, meaning server components are changing the state of energy from electricity to heat. Heat transform from electrical component to air within the server. Fan inside server is facilitating this heat transfer. Some system uses liquids to absorb and carry heat generated from ITE.Figure (2) gives standard air flow path through server equipment as per ASHRAE standard nomenclature [3]
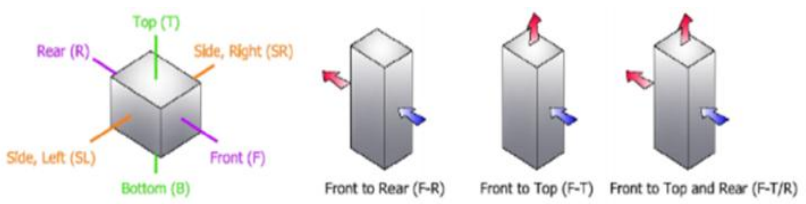

Figure 2ASHRAE standard nomenclature for air flow paths through server equipment

\section{2 .Space Cooling:}

In previous generation data center, heated air comes from server is mixed with open air and eventually moves to Computer Room Air Conditioner (CRAC) or Computer Room Air Handler (CRAH). CRAC and CRAH use refrigerant and chilled water as cooling coil respectively. Figure (3) shows the system architecture of CRAC and CRAH

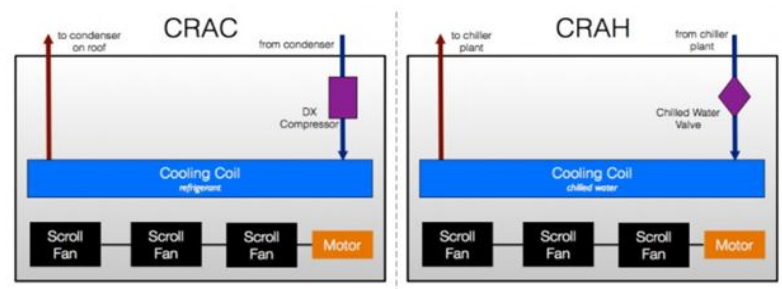

Figure 3System Architecture of CRAC and CRAH

\subsection{Fluid Conditioning:}

Tempering and returning fluid to the white space, to maintain appropriateconditions within the space. This research paper uses Cold Logik and RDHx as solution to save energy and power of data center and improves efficiency

\subsection{Heat Rejection:}

Once heat air is removed from free space in data center, it must be rejected to heat sink. The heat sink can be atmosphere or any other systems. Some of well-known system are:

\section{- $\quad$ CRAC or CRAH systems}

- Pumped liquid and cooling tower

- $\quad$ Direct Evaporative Cooling (DEC)

- Indirect Evaporative Cooling (IEC)

\section{Literature Review}

For effective Internet services without any disruption, Data center must provide reliable infrastructure and capable of supporting more users. To ensure the servers are up and running, it requires more power, increased operational costs. About $70 \%$ of budget is utilized for Servers and expenses towards maintaining temperature. Brandon Heller et all, present ElasticTree, a network-wide power manager, which dynamically adjusts the set of active network elements, links and switches to satisfy changing data center traffic loads [5].

In Data center, it is essential to have right power consumption models to optimizing energy-efficient operations and saving operational cost. Miyuru Dayarathna et all, survey the techniques used for energy consumption modelling [6]. They conduct an in-depth study of the existing data center power modelling, covering more than 200 models. The team organize these models focusing on hardware-centric and software-centric power models. In hardwarecentric approaches, they covered from the digital circuit level and move on to energy consumption models at the hardware component level, server level, data center level, and finally systems of systems level. In software-centric approaches, they investigate power models developed for operating systems, virtual machines and software applications.

Power consumed in data centers is having huge impacts on environments. There are several approaches followed to reduce power consumption and save energy while keep the desired quality of service or service level objectives. In server consolidation approach, Virtual Machine (VM) technology has been widely applied in data center environments to host multiple virtual servers on base server [7]. Liang Liu et all did research on how to save energy using VM and present the GreenCloud architecture, which aims to reduce data center power consumption, while guarantee the performance from users' perspective. Green Cloud architecture enables comprehensive online-monitoring, migration and optimization through VM. To verify the efficiency and effectiveness of the proposed architecture, they took an online real-time game, Tremulous, as a VM application and the results show that they can save up to $27 \%$ of the energy when applying Green Cloud architecture

Cloud, green, grid and computing are more of commercial for few organizations. Only very few are succeed and able to produce stable products on this area. Vendors and consumers are keen to optimize the services offered through cloud data centers as much as possible. There are various methods which help to bring down rise in temperatures of servers in cloud data center infrastructure. Sahana et all, approached the problem in a new lightconcentrating on server utilization to regulate the temperature [9]. They introduced Mean Utilization Factor concept that allows detecting and regulating the amount of cool air that is to be channelled in and around the servers within a cloud data center to bring down the operating temperature

\section{Problem Statement}

Data center managers are expected to do more than ever including managing heterogeneous data sources, rapid growth in data volume and managing mission critical applications. They are also able to meet challenging service level agreements (SLA) and implementing green computing business initiatives. They are also expected to do less including reduced man power, less budget and saving energy and power consumption. 4IR revolution gave more opportunities to industries and several tools and systems are avail- 
able with improved processes. By leveraging these technology improvements, Data centers are driving towards improved data storage and server utilization, manage physical and virtual environment and reduce capital and operational expenses.

This research focuses on possible ways to

- $\quad$ Providing an cost effective and efficient DC to support the on-going Business

- $\quad$ Adding more devices in the existing space

- Reduction in cooling cost

- Reduction in power cost

- Reduction in overall operational cost

Threat and Opportunity analysis is done with the existing infrastructure and available devices and what will happen if no changes are made in the current data center. Table (2) gives threat and opportunities matrix for both long and short term

Table 2Threat and Opportunities for short and long term

\begin{tabular}{|c|c|c|}
\hline & $\begin{array}{l}\text { Threat (if no changes are } \\
\text { made) }\end{array}$ & $\begin{array}{l}\text { Opportunities (if changes } \\
\text { are made) }\end{array}$ \\
\hline 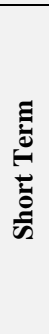 & 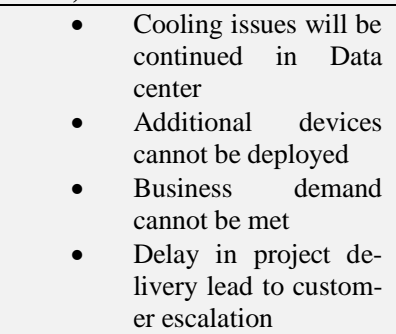 & $\begin{array}{l}\text { - Able to host addi- } \\
\text { tional servers } \\
\text { Business demand } \\
\text { can be met } \\
\text { - Operational cost } \\
\text { will be reduced }\end{array}$ \\
\hline لِّ & $\begin{array}{l}\text { - The cooling provided } \\
\text { is not sufficient which } \\
\text { causes hotspots in the } \\
\text { Data Center \& occa- } \\
\text { sional performance } \\
\text { issues. } \\
\text { There is no capacity } \\
\text { to install the IT hard- } \\
\text { ware since there is a } \\
\text { cooling capacity and } \\
\text { space constrain. } \\
\text { Addition of Precision } \\
\text { Air Handling Unit } \\
\text { (PAHU) type cooling } \\
\text { units \& racks are not } \\
\text { possible as there is no } \\
\text { space. }\end{array}$ & $\begin{array}{l}\text { Rack utilization } \\
\text { would improve } \\
\text { thereby can host } \\
\text { more servers } \\
\text { Close coupled } \\
\text { cooling improves } \\
\text { efficiency tremen- } \\
\text { dously } \\
\text { Able to generate } \\
\text { energy saving from } \\
\text { day1 \& also simul- } \\
\text { taneously have im- } \\
\text { proved cooling in } \\
\text { the DC he density } \\
\text { The high } \\
\text { RDHx cooling } \\
\text { units will give tri- } \\
\text { ple the current } \\
\text { cooling capacity }\end{array}$ \\
\hline
\end{tabular}

\section{Proposed Solution}

This research paper focuses on adding additional servers in the existing rack where data center has cooling issues due to which unable to add additional severs. This data center has $190+$ devices including firewall, routers and servers in 25 racks placed in 990 square feet. In this data center, there is no space to install new racks and new devices. Even Precision Air Handling Unit (PAHU) will not sustain to provide the cooling on adding new devices like server, Network, EMC Storages which will dissipate British Thermal Unit (BTU). To install new server rack, it takes 1124 minutes of cycle time which should be reduced to support ongoing deliverables and business units.

\subsection{Lean Analysis}

After analysing various solutions to save energy and power, it is decided to implement RDHx to resolve existing problem. Table (3) gives analysis performed on identified problem, improvement and benefit after installing RDHx.

\begin{tabular}{|c|c|c|c|c|}
\hline Operation & Problem & $\begin{array}{l}\text { Imple- } \\
\text { mented } \\
\text { Solution }\end{array}$ & Result & $\begin{array}{l}\text { Waste } \\
\text { Reduc- } \\
\text { tion }\end{array}$ \\
\hline
\end{tabular}

\begin{tabular}{|c|c|c|c|c|}
\hline $\begin{array}{l}\text { RDHx Im- } \\
\text { plementation }\end{array}$ & $\begin{array}{l}\text { Existing } \\
\text { cooling } \\
\text { method is } \\
\text { not effi- } \\
\text { cient } \\
\text { which } \\
\text { causes } \\
\text { hotspots in } \\
\text { the Data } \\
\text { Center \& } \\
\text { occasional } \\
\text { perfor- } \\
\text { mance } \\
\text { issues } \\
\text { Space } \\
\text { Crunch } \\
\text { due to } \\
\text { which } \\
\text { unable to } \\
\text { host addi- } \\
\text { tional rack } \\
\text { Increased } \\
\text { Operation- } \\
\text { al Cost }\end{array}$ & $\begin{array}{l}\text { Proposed } \\
\text { RDHx and } \\
\text { Cold logic } \\
\text { solution will } \\
\text { help to host } \\
\text { minimum } \\
16 \text { servers } \\
\text { and } 22 \\
\text { network } \\
\text { devices } \\
\text { Reduce } \\
\text { energy } \\
\text { consump- } \\
\text { tion of } \\
\text { chiller and } \\
\text { PAHU unit } \\
\text { Decrease } \\
\text { Space re- } \\
\text { quirements }\end{array}$ & $\begin{array}{l}\text { Would } \\
\text { result in } \\
\text { reduction in } \\
\text { the cooling } \\
\text { cost and } \\
\text { power cost } \\
\text { Reduced the } \\
\text { overall } \\
\text { operational } \\
\text { cost } \\
\text { Consolida- } \\
\text { tion of } \\
\text { computing } \\
\text { equipment } \\
\text { into the } \\
\text { existing } \\
\text { racks } \\
\text { Increasing } \\
\text { valuable } \\
\text { floor space } \\
\text { or enabling } \\
\text { expansion }\end{array}$ & $\begin{array}{l}\text { Cooling } \\
\text { leakages } \\
\text { and inef- } \\
\text { ficiency is } \\
\text { arrested } \\
\text { Space } \\
\text { Crunch is } \\
\text { arrested } \\
\text { Power } \\
\text { Usage } \\
\text { Efficiency } \\
\text { will be } \\
\text { achieved } \\
\text { Efficien- } \\
\text { cy of the } \\
\text { Chiller } \\
\text { would be } \\
\text { increased }\end{array}$ \\
\hline
\end{tabular}

\subsection{High Energy Consumption and Operational Cost}

While analyzing reason for increased cost and high energy consumption, it is observed that major expenses came from ensure availability of servers, energy and space, machine maintenance cost and man power. Figure (4) provides outcome of root cause analysis of higher cost.

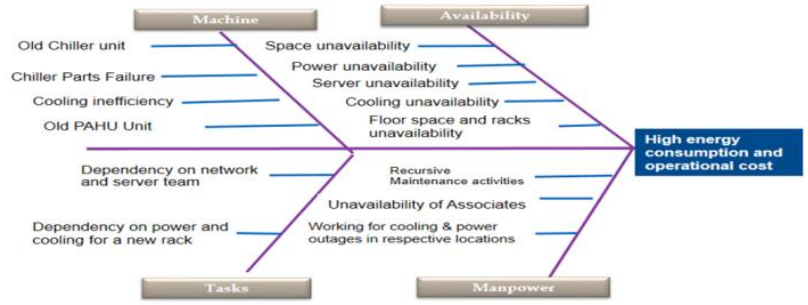

Figure 4Root Cause Analysis for High Energy Consumption and Operational Cost

\subsection{Working Principle of RDHx and Cold Logic Works}

By implementing RDHx cooling technology, without increasing space, can add more servers in each rack. Heat disputation from the servers will not affect the DC area through this solution. RDHx devices can eliminate chiller energy because they can use treated water from a plate-and-frame heat exchanger connected to a cooling tower. These inherent features of a RDHx help reduce energy use while minimizing maintenance costs

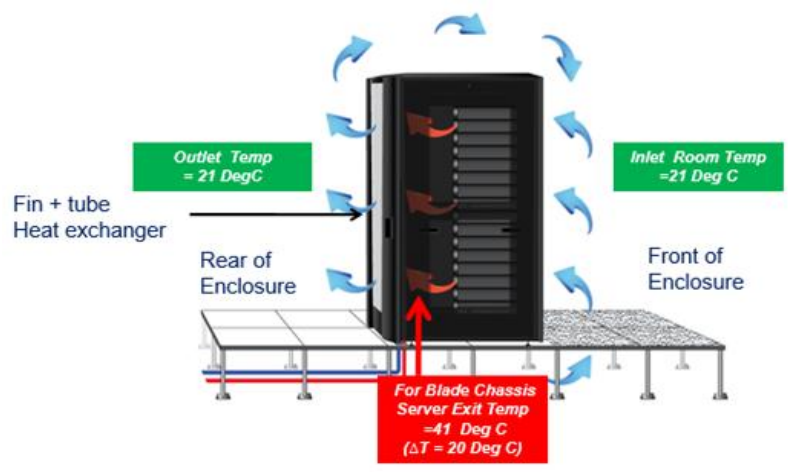

Figure 5How RDHx and Cold logik works 
Figure (5) demonstrates how RDHx works in data center.

- Inlet and outlet temperature remains the same Rear Door Heat Exchanger (RDHx) \& Cold Logik replaces existing rear door of Data Center Racks.

- Chilled water in RDHx circulates through heat exchanger from supply connections.

- Once RDHx is installed, it doesn't require direct electrical energy to operate.

- Equipment exhaust air passes through coil and is cooled before re-entering the room.

- Heat is rejected from room through return water connection.

- RDHx \& Cold Logik provides $100 \%$ sensible cooling.

- No condensation, no need for reheat or humidification.

- CDU creates a fully isolated, temperature controlled secondary loop

- Chilled water source - city water, building chilled water, packaged chiller and central return CRAC water.

\subsection{Thermal Image Comparison}

The improvements on air temperature in data center are compared with thermal image picture which is used for capturing heat energy into visible light. Figure (6) has picture taken from normal camera, thermal picture of before and after RDHx implementation.
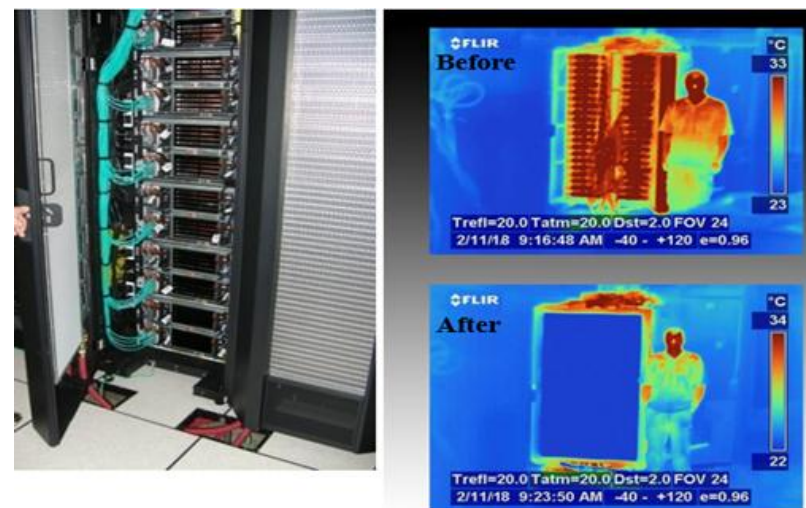

Figure 6Thermal Image taken on a $23 \mathrm{KW}$ Cabinet

\section{Execution Approach}

Whenever there is a change in Data center, it is important to ensure that there will not be shut down for longer duration and there will not be any impact on regular operations including development and support activities. After implementation, efficiency and cost analysis to be done in all major areas including consolidation and utilization of servers, space management and energy consumption and reduction in man power

\subsection{Precision Air Handling Unit (PAHU) maintenance}

This data center has more than 190 devices which are handled by 7 users. Time and effort consumed for PAHU activities are reduced by $64 \%$ as per sample data from 5 different users. The activities performed by users and time taken for each activity.

Table (4) and Table (5) are time consumed by different users before and after implementation of RDHx. This table didn't consider idle time between activities and considered only active duration in minutes. Average time consumed for completing all activities is reduced from 771 minutes to 492 minutes which is more than $64 \%$
Table 4Pre Implementation Time and Motion study for PAHU activities

\begin{tabular}{|l|l|l|l|l|l|l|l|}
\hline \multicolumn{7}{|c|}{ Pre Implementation Time (in Minutes) } \\
\hline $\begin{array}{l}\text { Activities / } \\
\text { User }\end{array}$ & $\mathbf{1}$ & $\mathbf{2}$ & $\mathbf{3}$ & $\mathbf{4}$ & $\mathbf{5}$ & Total & Average \\
\hline $\begin{array}{l}\text { Ensure the } \\
\text { Application, } \\
\begin{array}{l}\text { Databases } \\
\text { down }\end{array}\end{array}$ & 155 & 175 & 150 & 185 & 195 & 860 & 172 \\
\hline $\begin{array}{l}\text { After con- } \\
\text { firming with } \\
\text { the Applica- } \\
\text { tion owner } \\
\text { proceeding } \\
\text { with the serv- } \\
\text { ers shut down }\end{array}$ & 120 & 100 & 115 & 95 & 85 & 515 & 103 \\
\hline $\begin{array}{l}\text { SAN Switch } \\
\text { Post disable }\end{array}$ & 8 & 7 & 5 & 9 & 6 & 35 & 7 \\
\hline $\begin{array}{l}\text { Network } \\
\text { devices Port } \\
\text { disable }\end{array}$ & 10 & 7 & 8 & 6 & 10 & 41 & 8 \\
\hline $\begin{array}{l}\text { PAHU } \\
\text { maintenance } \\
\text { Activity }\end{array}$ & 215 & 210 & 205 & 200 & 210 & 1040 & 208 \\
\hline $\begin{array}{l}\text { Network } \\
\text { devices Port } \\
\text { enable }\end{array}$ & 5 & 7 & 6 & 9 & 5 & 32 & 6 \\
\hline $\begin{array}{l}\text { SAN Switch } \\
\text { Post enable }\end{array}$ & 4 & 3 & 7 & 5 & 3 & 22 & 4 \\
\hline $\begin{array}{l}\text { Servers pow- } \\
\text { ered on }\end{array}$ & 90 & 85 & 95 & 90 & 88 & 448 & 90 \\
\hline $\begin{array}{l}\text { Start applica- } \\
\text { tion, data- } \\
\text { bases, verifi- } \\
\text { cation }\end{array}$ & 155 & 175 & 150 & 185 & 195 & 860 & 172 \\
\hline Total Time & $\mathbf{7 6 2}$ & $\mathbf{7 6 9}$ & $\mathbf{7 4 1}$ & $\mathbf{7 8 4}$ & $\mathbf{7 9 7}$ & $\mathbf{3 8 5 3}$ & $\mathbf{7 7 1}$ \\
\hline
\end{tabular}

Table 5Post Implementation Time and Motion study for PAHU activities

\begin{tabular}{|c|c|c|c|c|c|c|c|}
\hline 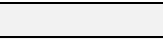 & Post & nplem & ntation & Time ( & $\mathrm{Min}$ & & \\
\hline $\begin{array}{l}\text { Activities / } \\
\text { User }\end{array}$ & 1 & 2 & 3 & 4 & 5 & Total & Average \\
\hline $\begin{array}{l}\text { Ensure the } \\
\text { Application, } \\
\text { Databases } \\
\text { down }\end{array}$ & 75 & 70 & 80 & 85 & 75 & 385 & 77 \\
\hline $\begin{array}{l}\text { After con- } \\
\text { firming with } \\
\text { the Applica- } \\
\text { tion owner } \\
\text { proceeding } \\
\text { with the } \\
\text { servers shut } \\
\text { down }\end{array}$ & 85 & 80 & 75 & 90 & 70 & 400 & 80 \\
\hline $\begin{array}{l}\text { SAN Switch } \\
\text { Post disable }\end{array}$ & 8 & 7 & 5 & 9 & 6 & 35 & 7 \\
\hline $\begin{array}{l}\text { Network } \\
\text { devices Port } \\
\text { disable }\end{array}$ & 10 & 7 & 8 & 6 & 10 & 41 & 8 \\
\hline $\begin{array}{l}\text { PAHU } \\
\text { maintenance } \\
\text { Activity }\end{array}$ & 115 & 110 & 105 & 100 & 110 & 540 & 108 \\
\hline $\begin{array}{l}\text { Network } \\
\text { devices Port } \\
\text { enable }\end{array}$ & 5 & 7 & 6 & 9 & 5 & 32 & 6 \\
\hline $\begin{array}{l}\text { SAN Switch } \\
\text { Post enable }\end{array}$ & 4 & 3 & 7 & 5 & 3 & 22 & 4 \\
\hline $\begin{array}{l}\text { Servers pow- } \\
\text { ered on }\end{array}$ & 90 & 85 & 95 & 90 & 70 & 430 & 86 \\
\hline $\begin{array}{l}\text { Start applica- } \\
\text { tion, data- } \\
\text { bases, verifi- } \\
\text { cation }\end{array}$ & 115 & 125 & 110 & 105 & 120 & 575 & 115 \\
\hline Total Time & 507 & 494 & 491 & 499 & 469 & 2460 & 492 \\
\hline
\end{tabular}

\subsection{Energy and Consumption Comparison}

In this section, analysis on how electricity consumption is saved before and after implementation of this cooling technology. This 
comparison assumes that there is no additional load during this analysis. Table (6) shows comparison power consumption (in Watt) before and after implementation for 12 months. From this data, it is clear that $11.5 \%$ power saved in a year.

Table 6Power consumption (in Units) for 12 months

\begin{tabular}{|l|r|r|r|}
\hline Month & $\begin{array}{l}\text { Pre Implementa- } \\
\text { tion }\end{array}$ & $\begin{array}{l}\text { Post Implementa- } \\
\text { tion }\end{array}$ & \multicolumn{1}{c|}{ Diff } \\
\hline Mon 1 & 536932 & 416880 & $\begin{array}{r}12005 \\
2\end{array}$ \\
\hline Mon 2 & 548304 & 428202 & $\begin{array}{r}12010 \\
2\end{array}$ \\
\hline Mon 3 & 486292 & 453766 & 32526 \\
\hline Mon 4 & 434992 & 423244 & 11748 \\
\hline Mon 5 & 436572 & 429380 & 7192 \\
\hline Mon 6 & 465870 & 449716 & 16154 \\
\hline Mon 7 & 421114 & 396770 & 24344 \\
\hline Mon 8 & 414672 & 395994 & 18678 \\
\hline Mon 9 & 430192 & 339054 & 91138 \\
\hline $\begin{array}{l}\text { Mon } \\
10\end{array}$ & 388370 & 326307 & 62063 \\
\hline $\begin{array}{l}\text { Mon } \\
11\end{array}$ & 367930 & 313302 & 54628 \\
\hline $\begin{array}{l}\text { Mon } \\
12\end{array}$ & 363762 & 318778 & 44984 \\
\hline \begin{tabular}{l} 
Total \\
\hline
\end{tabular} & 5275002 & 4691393 & 60360 \\
9
\end{tabular}

\section{Conclusionand Future Work}

This paper presents implementation of RDHx cooling strategy combined with cold logik to reduce energy and power consumption and reducing operational expenses. By implementing RDHx, cooling cost, power cost, operational cost and effective utilization of spaces can be achieved in any data center. There is no need to shutdown data center for this migration process. After installing RDHx, PAHU and PAU can be switched off completely which is direct cost savings on cooling. Due to increased inlet water supply, the efficiency of chiller unit is improved. Hotspot free Data center is possible by implementation of RDHx and HOT and COLD tile is not required. These are prime reasons for saving data center operational cost.

4IR generates more data and lead to technology advancement faster than expected ration. More money and too much time are spent on 4IR to standardize and prove technologies in market. Among all challenges, few well established technologies influences the industry to save cost, energy and power in Data center. RDHx and cold logik are one among simple and inexpensive which is suitable for Tier 4 data centers. For next few years, there will not be much advancement technologies to transform data centers. Some improvements are expected to save power and energy efficiency in next generation data center through below approaches

- More efficiency on power distribution and combined cooling technologies including free cooling

- $\quad$ Right selection of tier and place for data center which support zero downtime

- $\quad$ Realistic target for data center power usage target.

Transform towards elevated data center temperature

\section{References}

[1] "Telecommunications Infrastructure Standard for Data Centers". ihs.com. 2005-04-12. Retrieved 2017-02-28

[2] Pruhs, K. Green computing algorithmic. In Proceedings of the 2011 IEEE 52nd Annual Symposium on Foundations of Computer Science (FOCS), Palm Springs, CA, USA, 22-25 October 2011; pp. $3-$ 4
[3] 2008 ASHRAE Environmental Guidelines for Datacom Equipment, ASHRAE white paper.

[4] Luca Parolini, Bruno Sinopoli, Bruce H. Krogh "Reducing Data Center Energy Consumption via Coordinated Cooling and Load Management" usenix, The advanced computing system association. (https://www.usenix.org)

[5] Brandon Heller, SriniSeetharaman, PriyaMahadevan, YiannisYiakoumis, Puneet Sharma, Sujata Banerjee, Nick McKeown "ElasticTree: Saving Energy in Data Center Networks" (https://www.usenix.org/legacy/event/nsdi10/tech/full_papers/heller .pdf)

[6] M. Dayarathna, Y. Wen and R. Fan, "Data Center Energy Consumption Modeling: A Survey," in IEEE Communications Surveys \& Tutorials, vol. 18, no. 1, pp. 732-794, Firstquarter 2016.

[7] Liang Liu, Hao Wang, Xue Liu, Xing Jin, Wen Bo He, Qing Bo Wang, Ying Chen "GreenCloud: a new architecture for green data center" ICAC-INDST '09 Proceedings of the 6th international conference industry session on Autonomic computing and communications industry session

[8] Felipe Abaunza, Ari-PekkaHameri, TapioNiemi, (2018) "EEUI: a new measure to monitor and manage energy efficiency in data centers", International Journal of Productivity and Performance Management, Vol. 67 Issue: 1, pp.111-127

[9] Sahana S., Bose R., Sarddar D. (2018) Server Utilization-Based Smart Temperature Monitoring System for Cloud Data Center. In: Bhattacharyya S., Sen S., Dutta M., Biswas P., Chattopadhyay H. (eds) Industry Interactive Innovations in Science, Engineering and Technology. Lecture Notes in Networks and Systems, vol 11. Springer, Singapore 